\title{
Jovens delinqüentes paulistanos
}

Antonio Sergio Spagnol

Os jovens que se envolvem com a delinqüência na cidade de São Paulo sempre chamaram a atenção de especialistas de diferentes áreas, e a literatura dos últimos anos tem oferecido farto material para a elaboração de muitas análises. Segundo alguns estudos, a primeira causa de mortalidade entre os jovens na faixa de 15 a 24 anos é o homicídio. O número de jovens que morrem assassinados no Brasil, segundo a Polícia Militar, é quase sete vezes maior do que o número de vítimas de homicídios na população total. No ano de 2000, nas Febens do estado de São Paulo, a PM registrou o dobro de internações de adolescentes acusados de prática de homicídio e tentativa de homicídio. As explicações para isso seguem várias direções, passando pela delinqüência, a exclusão social, a cultura adolescente, as gangues de rua, até o crime organizado.

É interessante notar também que essa violência passou a ser o foco de preocupaçôes dos próprios jovens. Pesquisas mostram que para $49 \%$ dos jovens que habitam centros urbanos o principal medo e o que faz com que se sintam mais ameaçados é a violência, independentemente da região em que moram. Segundo dados da Fundação Perseu Abramo (2001), na região metropolitana de São Paulo, 42\% dos jovens afirmaram já ter visto pessoalmente alguém assassinado, e em cada três jovens um já foi assaltado. Outros estudos (cf. Diógenes, 1998; Costa, 1993; Salem, 1995; Guimarães, 1998; Vianna, 1998) chamam a atenção para jovens que se agrupam 
1. O estudo de Diógenes (1998), por exemplo, mostra como se organizam as gangues da cidade de Fortaleza, Ceará. em gangues para suas práticas delinqüenciais. No caso de Brasília, por exemplo, Waiselfisz (1998) mostra que, de todos os jovens internados nas Febens daquela cidade, cerca de $50 \%$ já pertenceram ou tiveram ligações com gangues de rua, bandos ou quadrilhas ${ }^{1}$.

Os internos da Febem de São Paulo que praticaram roubo ou furto representam $67 \%$ do total, e a taxa daqueles que cometeram homicídios fica em torno de 8,5\% (cf. Febem, 2000). Mesmo assim, o homicídio é a modalidade de crime que mais chama a atenção da população em geral e provoca reaçôes mais dramáticas do que outros tipos de crimes, principalmente o homicídio que choca pela extrema violência com que é praticado. $\mathrm{O}$ que mais impressiona é a crueldade com que os jovens tratam suas vítimas. Não é somente matar, atirar ou esfaquear uma pessoa, mas torturá-la, cortar, furar, amassar, destruir seu corpo de maneira desumana, sem demonstrar nenhum sinal de arrependimento. Pelo contrário - e o que se mostra ainda mais perturbador -, parece haver prazer em matar, em destruir o outro de maneira bárbara e cruel. Essa preocupação com a forma como é feito o crime, por parte de jovens ainda adolescentes, revestida de uma raiva extrema, revela algo inquietante nas relações sociais. E a sociedade, de maneira geral, responde com preconceito e discriminação proporcionais à violência cometida.

A partir de uma pesquisa de campo realizada na cidade de São Paulo, no período de 1999 a 2002, tentei analisar esse fenômeno, que me pareceu tão particular quanto amedrontador. $\mathrm{O}$ objetivo deste artigo é revelar como se desenvolveu essa pesquisa e levantar questóes relativas ao comportamento desses jovens, bem como esclarecer uma possível relação com as chamadas "gangues de jovens" e o envolvimento de jovens pertencentes às classes média e alta na prática de homicídios.

A pesquisa teve início com entrevistas com os internos na Febem Tatuapé, que relataram com riquezas de detalhes como cometeram seus crimes. Por meio dessas entrevistas, pude chegar a outros adolescentes em diferentes locais da cidade. Para o trabalho de campo limitei-me à Zona Sul de São Paulo, e a pesquisa se concentrou em bairros como Jardim Ângela e Capão Redondo, com elevadas taxas de homicídio de uma maneira geral e que figuram entre os mais violentos da cidade. $O$ primeiro já chegou a ser considerado um dos bairros mais violentos do mundo. Também foi escolhida a favela de Paraisópolis, que pode ser considerada um laboratório de pesquisas, dados os inúmeros estudos de que foi objeto. É uma das maiores favelas da cidade e faz uma espécie de ligação entre os dois bairros citados e o 
Morumbi, bairro nobre da capital. Foram tomados também dois municípios da região metropolitana de São Paulo, Taboão da Serra e Embu, ambos na região sul da cidade. Para efeito de comparação, foram utilizados três bairros considerados nobres na cidade, o próprio bairro do Morumbi, cercado pela favela de Paraisópolis, e os bairros de Moema e Itaim-Bibi.

Ao entrar nesse mundo, acreditava que meus personagens se escondiam nesses locais, mas percebi que, na verdade, sequer conseguiam sair deles. Caminhando entre os barracos das favelas e as casas mal acabadas da periferia, encontrava jovens armados que conversavam comigo tranqüilamente, provocando uma sensação estranha: diante de um jovem manuseando uma arma, contando-me como ele matou suas vítimas, precisava concentrar-me na pesquisa proposta e, ao mesmo tempo, descobrir as "rotas de fuga", dos barracos, das vielas estreitas, como se tivesse que escapar a qualquer momento. Uma sensação não muito diferente surgia ao entrevistar os jovens que habitavam as regiōes consideradas nobres da cidade: em Moema, no Itaim-Bibi ou no Morumbi, os relatos dos jovens também provocam medo e estavam impregnados de desespero.

Não há estudos sobre a delinqüência entre os jovens pertencentes às classes média e média alta. Entretanto, essa delinqüência existe, mas as informações não chegam a público e seus familiares entram em cena imediatamente para que não haja a menor possibilidade de o adolescente ingressar na Febem como infrator. A mídia também colabora. As notícias que geram maiores polêmicas são as de crimes praticados por adolescentes oriundos $\mathrm{da}$ periferia, principalmente se forem cometidos contra a classe média. Quanto mais violento, sangrento e espetacular o crime, melhor para a mídia, pois ele funciona como um forte atrativo. A violência, apresentada sobretudo como algo perturbador e descontrolado, pode denotar uma crise em relação ao Estado (cf. Michaud, 1998), que se apressa a apresentar inúmeros projetos visando à reintrodução do jovem infrator à sociedade. O papel da mídia, segundo Thompson (1999), é provocar o medo, principalmente na classe média, insistindo que a violência é oriunda das classes baixas. A intenção é alardear constantemente que a violência está em todas as partes, a todos os momentos. Glassner (1999), um estudioso da mídia norte-americana, diz que a imprensa provoca o medo não no intuito de levantar o debate sobre a violência, mas sobretudo para transformá-la num evento dramatizado aos olhos da população.

Quando há debates, de maneira geral seguem divididos em duas frentes: uma defende que o aumento da criminalidade juvenil é conseqüência 
2. Regiōes como Cidade Ademar, Jardim Ângela, Sapopemba e Jabaquara, que são também as regiōes onde se concentra o maior índice de desemprego. Esses jovens são os mais atingidos e a violência impera nesse meio, o que os força a se unirem em busca de segurança. Para alguns, pertencer a um grupo pode ser uma estratégia de garantia contra a violência. Contudo, o mesmo grupo que dá a sensação de segurança pode se tornar uma ameaça, já que pode ter a conotação de "bandidagem" ligada à violência (cf. Cardia, 1998): se a uniāo em grupos ou outras modalidades de associação oferece num primeiro momento segurança, essa mesma segurança pode ser convertida em segregação por parte da comunidade, que encara o grupo como ação de marginais. da falta de elaboração, por parte do Estado, de uma política eficaz no combate a esse tipo de infração penal. Defendem o recrudescimento dos instrumentos legais que inibem a ação criminal dos adolescentes e a diminuição da idade penal, bem como maior severidade nas aplicaçôes das penas e, muitas vezes, a idéia da pena de morte, para alguns casos. A segunda frente discute o ECA - Estatuto da Criança e do Adolescente, promulgado em 1990 - e sua real aplicação por parte do Estado. Acusam o Estado de omissão em relação ao estatuto e de não desenvolver uma política voltada para o bem-estar do adolescente infrator.

Como fruto desses debates, surgiram diversas organizações dispostas a propor soluções práticas, principalmente quanto à recuperação de menores infratores, como aqueles internados nas unidades das Febens de São Paulo. Há também inúmeros projetos direcionados aos jovens moradores de diferentes bairros da capital, especialmente os da periferia. A tentativa, de maneira geral, é resgatar esse jovem do mundo da delinqüência e/ou não permitir sua entrada nele. Mas, apesar de todas essas iniciativas, o problema parece persistir, e a delinqüência juvenil continua ganhando destaque e preocupando a sociedade, sobretudo a participação de jovens nos chamados crimes violentos.

Os crimes cometidos por jovens de classe média que chegam à mídia não são vistos, de uma maneira geral, como crimes cometidos por "assassinos", "monstros", "homicidas", mas por jovens que apresentam "algum problema" que não conseguimos detectar. A questão principal que se discute nesses casos é o tipo de educação ou problemas não detectados nas relaçôes entre pais e filhos. A pergunta que se faz é: "Onde foi que erramos?".

Apesar de encontrarmos jovens de classe média envolvidos com a criminalidade, a grande maioria dos adolescentes internados na Febem de São Paulo é oriunda da periferia da cidade e pertencente às classes trabalhadoras pauperizadas ${ }^{2}$. Mas é interessante notar que nessa mesma periferia encontramos adolescentes submetidos às mesmas condições sociais que em nenhum momento de suas vidas envolveram-se com o mundo do crime. Pelo contrário, possuem muitas vezes um discurso de oposição aos demais. No meio do caos em que se encontram, parece que ainda buscam uma normalidade de vida no binômio escola-trabalho, que lhes dê um mínimo de esperança de melhoria de suas condições.

É fato também que a maioria dos adolescentes que cometem delitos não está sozinha nessas ações, mas conta com a colaboração de amigos, 
vizinhos e até mesmo de pessoas que mal conhecem. Essa união, muitas vezes momentânea, é considerada, na maior parte dos casos, uma espécie de organização entendida como "gangue", bando ou quadrilha. A mídia, por sua vez, traz esse fenômeno para pauta do dia. Há um grande alarde sobre as atitudes desses adolescentes, principalmente quando envolve crime de morte ou crimes que caminham no sentido periferia-centro. Nos últimos anos, esse fenômeno passou a ser percebido como um problema social e ganhou estatuto de questão nacional.

Contudo, a pobreza por si só não explica a violência nessas áreas, palco de nossa pesquisa, uma vez que os dados sobre outras regiōes da cidade, igualmente miseráveis, apresentam um número menor de adolescentes infratores. Além disso, mesmo nas áreas mais miseráveis, apenas uma parcela dos adolescentes envereda para o campo da delinqüência. Outros elementos devem existir que indiquem as causas desse fenômeno.

O modo de inserção social dos jovens de diferentes grupos na cidade de São Paulo pode ser distinto, mas há uma marca em todos eles: o uso da violência como forma maior de expressão. Apesar de esse tema ser considerado preocupante no cenário nacional, a violência envolvendo adolescentes não é assunto recente e nem menos debatido. $\mathrm{O}$ interesse da sociedade por esse fenômeno vem do século passado e suas diferentes propostas de soluções caminharam sempre juntas.

\section{As gangues}

A literatura norte-americana oferece-nos inúmeros estudos sobre a formação de gangues de jovens delinqüentes. A maioria aponta para o fato de que as gangues são coletivos formalizados nos quais o objetivo principal é proporcionar ganhos econômicos e sociais a seus membros.

Segundo Klein (1995), gangue pode ser qualquer grupo de adolescentes cujos membros sejam reconhecidos pelos moradores de determinado território como pertencentes a um grupo; identifiquem-se eles mesmos como pertencentes ao grupo; e tenham cometido um número mínimo de delitos, fazendo com que a comunidade local, bem como as autoridades, desenvolvam em relação a eles e ao grupo atitudes negativas.

Com a deterioração das condições de vida das pessoas pertencentes às classes trabalhadoras e do relacionamento delas com o Estado, alguns jovens desenvolvem estratégias para se tornarem empreendedores - uma dessas estratégias é formar gangues. Em vez de rejeitarem a cultura, adaptam suas 
estratégias às oportunidades e aos recursos a que têm acesso. Em contrapartida, o Estado responde aprisionando e reprimindo seus membros, o que só faz fortalecê-los cada vez mais. Assim, para Jankowski (1997), as gangues influenciam a estrutura social à qual pertencem e a estrutura social da qual estão separadas, assim como influenciam e sofrem influência do meio no qual estão inseridas. Dessa maneira, o fenômeno das gangues seria tanto uma resposta às condiçôes estruturais da sociedade como parte integrante dessas condições.

O objetivo principal desse tipo de organização é proporcionar a seus membros, basicamente, vantagens econômicas e sociais. "Numa situação estrutural como essa, as principais atividades da gangue, como organização, destinam-se a assegurar os recursos financeiros necessários para proporcionar lazer a seus membros" (Idem, p. 30). Com a deterioração das condiçôes de vida das classes menos favorecidas e o retraimento do Estado nas questôes sociais, os adolescentes, principalmente aqueles oriundos de classes menos privilegiadas, buscam novas formas de sobrevivência. Em vez de rejeitarem a cultura econômica prevalecente, as gangues aceitam os princípios dessa cultura e adaptam suas estratégias às oportunidades e aos recursos que poderiam ter. Isso não significa que elas estejam empenhadas em acumular lucro, mas a perspectiva de ganhos, diante de uma situação econômica incerta, atrai certo número de jovens, sobretudo os oriundos de famílias pobres.

O jovem que deseja ingressar numa gangue deve passar por uma espécie de ritual de aceitação, que vai desde resistir a ser espancado até realizar pequenos furtos para satisfazer os interesses dos mais velhos. Ele deve seguir uma hierarquia - obediência aos líderes e uso dos códigos internos e informais para se comunicar. A união é que faz a força do grupo. As atividades econômicas cotidianamente desenvolvidas pelos componentes variam entre as diferentes gangues, e pode ir desde proteção aos comerciantes do bairro até participação em prostituição, passando por roubos e assaltos diversos (cf. Jankowski, 1991; Cohen, 1955).

Essas explicações sobre a formação das gangues, bem como a atuação de seus membros nas comunidades norte-americanas, mostram que o fenômeno proporciona ainda um vasto campo de pesquisa a ser investigado. O que parece ser um consenso nos estudos é que grande parte da violência das gangues norte-americanas está relacionada às questóes socioeconômicas. Para se manterem atuantes em meio à deterioração das condições de vida e do caos urbano em que se encontram, os jovens unem-se em gan- 
gues como estratégia de sobrevivência e adaptam tais estratégias às oportunidades e aos recursos a que têm acesso.

Nos Estados Unidos, as gangues ganharam espaço e fama. Elas mantêm relações estreitas com a polícia, por exemplo, que as utiliza para expandir seu conhecimento em áreas onde não consegue penetrar. Como não há uma política pública efetiva, as prisões dos membros das gangues tornamse um círculo vicioso. A polícia prende, mas algum tempo depois o jovem acaba sendo libertado. Assim, ambos - a polícia e os membros das gangues são beneficiados. No caso da imprensa, também há benefícios mútuos: ela se utiliza das gangues para obter histórias, pelas quais a comunidade pode ser influenciada, e a gangue se utiliza da mídia para inserir-se no espaço urbano e fortalecer-se.

Todas as explicações sobre as gangues norte-americanas, junto com aquilo que nos chega pela mídia impressa, e também o cinema, alimentam o imaginário social a respeito da delinqüência juvenil e, de certa forma, influenciam nosso olhar sobre os adolescentes infratores. Podemos pensar em gangues de delinqüentes no Brasil, em especial na cidade de São Paulo, tal como existem nos Estados Unidos?

No Brasil

No caso brasileiro, a utilização do termo gangue, quando se trata de delinqüência juvenil, parece ser aleatória, especialmente por parte da mídia. Com ele se define qualquer grupo de jovens que pratique diferentes atos infracionais. Quando um grupo é detido, não raro o termo gangue é utilizado para defini-lo, bastando que estejam presentes, no momento da detenção, mais de três jovens, mesmo que apenas suspeitos de um determinado ato infracional.

Outro termo muito utilizado no Brasil é bando, que geralmente é empregado para designar um grupo de delinqüentes organizado para um objetivo comum e imediato, como um assalto, um resgate de prisioneiro ou um ataque, que é seguido do desmantelamento do grupo.

A quadrilha, grupo formado por pelo menos quatro elementos, realiza ações semelhantes às do bando, mas não há necessariamente o desmantelamento do grupo. "As quadrilhas são compostas por um número relativamente pequeno de pessoas, em geral jovens, que se organizam com a finalidade de desenvolver atividades ilegais para o enriquecimento rápido de seus membros" (Zaluar, 1997, p. 44). Isto configura um dos 
pontos em comum entre as quadrilhas brasileiras e as gangues norte-americanas: a busca de enriquecimento rápido por vias ilegais.

Interessante também é a relação que os membros de uma quadrilha estabelecem com seus vizinhos. No Brasil, essas relações são bastante explícitas. Um dos pontos referentes ao pertencimento de uma quadrilha a determinado bairro é seu poder de interferir no cotidiano dos moradores (ao definir, por exemplo, dias de luto, toque de recolher em escolas, em ruas, a abertura do comércio etc.), constituindo o chamado poder paralelo. Diante da ineficácia da atuação do Estado na manutenção da ordem e da segurança, as quadrilhas tomam a dianteira, ora auxiliando os moradores da localidade, ora punindo com a expulsão deste ou daquele morador, bloqueando ruas, fechando estabelecimentos, entre outras formas de sanção. Os delinqüentes acabam ocupando o espaço deixado pelo Estado, que não supri as necessidades dos moradores, deixando-os à mercê daqueles. Grande parte aceita, ou é obrigada a aceitar, esse poder em troca de certa proteção. Os que não aceitam são punidos. Um dos pontos principais dessa anuência é a promessa da quadrilha de defender os moradores contra bandidos de outros bairros. Segundo Zaluar, que trata mais especificamente da cidade do Rio de Janeiro, "numa cidade cada vez mais dividida em territórios controlados por quadrilhas e comandos infestados de pequenos ladróes e estupradores, é a quadrilha local que respeita as regras de convívio com o trabalhador que exerce a segurança" (1997, pp. 47-48).

Dessa forma, "o território ocupado, ao mesmo tempo que é área de segurança dos bandidos, torna-se, para os moradores, um espaço protegido das agressões de elementos da própria área e de bandidos de fora" (Guimarães, 1998, p. 94). O poder dos traficantes aumenta quando conseguem dominar por completo o território, punindo os moradores que infringem as regras determinadas por eles.

$\mathrm{Na}$ cidade de São Paulo, não são raros os casos de violência que têm jovens como protagonistas - que a mídia classifica como "pertencentes a gangues", quadrilhas etc. -, e os motivos alegados são tentativa de invasão da área ou simplesmente um olhar "enviesado", constituindo os chamados crimes cometidos por motivos fúteis.

Os traficantes paulistas seguem o mesmo ritmo dos cariocas, apenas com alguns anos de atraso em relação ao controle e à administração do tráfico. Grande parte da violência perpetrada pelos traficantes das favelas paulistas tem também como causa o controle de territórios, disputa de pontos de venda de drogas e vingança entre os grupos. Os jovens e 
adolescentes, nesse contexto, participam como agentes e como vítimas. O jovem, especialmente morador da periferia, associa-se ao tráfico, assim como quando se organiza em quadrilhas, como forma de ascensão social rápida e de participação no mercado de consumo, inacessível de outra maneira.

No caso da cidade de São Paulo, as quadrilhas, sobretudo de traficantes de drogas, não parecem ocupar o papel do Estado no que diz respeito ao auxílio às comunidades. Não seguem a máxima de estar presente onde $o$ Estado é omisso. O controle maior é direcionado ao tráfico. A interferência na comunidade é grande no sentido de se fazer obedecer, como por exemplo ao proibir a circulação de carros e pessoas numa determinada parte da favela, fechar as portas dos estabelecimentos comerciais como forma de respeito a algum traficante morto ou impedir a passagem numa determinada rua da região. Isso tudo é imposto, salvo pequenas exceções, e nada é oferecido em troca, como ajuda aos doentes, reformas de casas ou construção de qualquer outro tipo de empreendimento que seja necessário para a comunidade. A imposição das vontades dos traficantes é respeitada pelo medo, e o silêncio é a resposta. Nesse contexto, a participação dos jovens como autores de crimes graves é extremamente reduzida. Eles aparecem num segundo plano ou como coadjuvantes dessas ações.

\section{Em São Paulo}

Não pude constatar em minha pesquisa a presença de jovens organizados em grupos com a finalidade de praticar crimes ou outras atividades ilícitas consideradas graves. Na cidade de São Paulo, pelo menos nas áreas por mim pesquisadas, não há indícios de jovens organizados em gangues, tal como esse fenômeno é definido por pesquisadores.

A preocupação principal em minha pesquisa reside nos jovens que praticam atos considerados graves, como os homicídios. Nos locais pesquisados, esses jovens não estão ligados a uma gangue ou a qualquer outro tipo de grupo. Eles estão, sim, ligados à comunidade e se identificam como tal. Em seus discursos, pode-se encontrar a região como característica principal de sua origem: "Sou de Santo Amaro", "Sou do Taboão", "Sou do Capão". Apesar de haver uma grande identificação com seus bairros e região, não há identificação com grupos ou gangues. Eles circulam pelos bairros como moradores, mas não como pertencentes a esse ou aquele grupo, e os relatos mostram tal independência: 
Resposta - Aí meu... num tem essa de grupo... de gangue... aqui é cada um por si. Se eu tenho uma treta cum camarada, eu vô lá e vejo o que dá... vô chamá?... ninguém não! É comigo memo...

Pergunta - Você nunca se envolveu com uma gangue aqui do Capão ou de Santo Amaro?

Resposta - Eu não... nunca vi esse negócio.

Pergunta - Mas como, se você falou que fez um assalto e estavam em quatro?

Resposta - Ah! Mas tudo camarada daqui... sem esse negócio de gangue. A gente tava aqui e falamo: vamo fazê?... Aí Zito [um amigo] disse: vamo chamá mais gente. Chamamo mais dois e falei: tá afim da fita? Tá? É isso... fizemo. Depois cabô... é isso aí... tá ligado?

Pergunta - Mas esses dois não eram seus amigos?

Resposta - Amigo?... ah, amigo assim... daqui, né? Tá ligado? Tavam sem fazê nada, aí veio com a gente! Depois acabô... se pintar outra fita quem sabe a gente vai de novo (R. S., 17 anos, Capão Redondo, internado três vezes na Febem Tatuapé por roubo).

Pergunta - Aqui no Taboão não tem gangue?

Resposta - Gangue?... Bem... o pessoal fala, né? O tráfico... coisa e tal.

Pergunta - Não... eu estou falando de jovens como você, 16, 17 anos... que se juntam em grupos pra fazer uma fita...

Resposta - Eu não conheço... Eu sempre fiz sozinho... quer dizer... de vez em quando, cê sabe... a gente faz junto.

Pergunta - Como funciona....

Resposta - A gente cumbina com um, com outro... o que tivé livre vai e quem tivé a fim, né? Mais daí é só... cabô, se pintá de novo... (W. P., 16 anos, Taboão.)

Os jovens envolvidos na criminalidade agem segundo a expectativa do momento, não há uma pré-elaboração de planos ou uma hierarquia. Os que atuam em grupos não se sentem obrigados a se submeter a uma estrutura hierárquica, a rituais de aceitação ou de qualquer outro tipo para participação na prática de delitos. O que há em São Paulo, em comparação, são quadrilhas, similares às existentes em outras capitais, mas a presença de jovens na estrutura geral delas é secundária em quantidade e importância. São poucos os adolescentes que controlam grupos de tráfico na cidade. Os jovens quadrilheiros atuam como mensageiros, olheiros, entregadores (aviōes) de drogas e até como matadores de clientes endividados e moradores que se opõem ao tráfico. Não ocupam o papel de grandes che- 
fes, de controladores do tráfico ou mesmo da "boca de fumo". Eles se reconhecem nessa posição ao se referirem aos comandantes por "pais", pois eles são, na verdade, filhos do tráfico.

O tráfico não deixa nenhuma dúvida quanto à forte atração que exerce sobre uma parte dos jovens da periferia. As entrevistas realizadas com jovens infratores em diferentes bairros de São Paulo indicam que esse "fascínio" pela delinqüência se expressa no desejo de dominar, impor sua vontade ao outro, e é visto por todos os demais membros como uma atitude de grande relevância. Num roubo ou num assalto, por exemplo, levar o fruto do roubo não é tão importante quanto humilhar o outro durante a ação dominar da forma como "bem entender", segundo eles. A satisfação após a ação criminosa pode ser notada quando recontam detalhes, para eles próprios, daquilo que presenciaram. $\mathrm{O}$ relato dos jovens os identifica como pertencentes ao grupo e legitima a ação. Acredito que essas ações podem indicar que as relações baseadas num princípio de reciprocidade estão de certa forma rompidas e podem, assim, fazer emergir outros laços sociais, baseados no fascínio pelo poder de destruição.

\section{Destruição}

Para a população em geral, é muito mais compreensível a ação de um indivíduo que rouba para sobreviver, que não tem o objetivo específico de matar o outro, mas se apossar de bens materiais, do que em relação àquele que anda armado e faz do roubo sua profissão e da morte do outro um meio de obtenção de prazer, um capricho. São os chamados crimes “insensatos", segundo Katz (1988).

Um jovem internado na Febem Tatuapé relatou como ele e um amigo terminaram com a vida de seu ex-patrão. $\mathrm{O}$ jovem trabalhava numa loja de ferramentas na região central da cidade de São Paulo havia dois anos. Segundo ele, seu patrão, de cerca de 60 anos, agia sempre como se ele, adolescente, fosse "um qualquer", sempre falando duro e de "cara feia". Diversas vezes o patrão, que morava sozinho e tinha apenas uma empregada, mandou que levasse compras pessoais até sua casa. Por detestar essa atividade, nutria a vontade de um dia poder assaltar aquela casa e, como o homem morava sozinho, acreditava que não encontraria grandes dificuldades. A idéia ganhou força quando o jovem foi demitido, segundo ele, "sem mais nem menos". Convidou um amigo da rua para a empreitada. Chegaram armados, de madrugada, e seguiram pela porta lateral, onde o 
rapaz sempre deixava as compras. Enquanto ele e o amigo reviravam a sala, foram surpreendidos pelo proprietário, que, espantado com a presença do ex-funcionário, questionou o porquê daquilo. Os rapazes não responderam e iniciaram uma sessão de espancamento descontrolada. Segundo ele, "chutavam tudo que viam na frente", apesar de armados.

Com uma espátula de abrir cartas, fizeram vários furos no corpo do homem, que faleceu no centro da sala em meio a uma poça de sangue. $\mathrm{O}$ adolescente, então, ergueu um vaso de flores "do tamanho de um balde" e soltou-o sobre a cabeça do ex-patrão, já morto. Antes de sair, o jovem voltou e pisou com a ponta do pé no sangue que estava no chão.

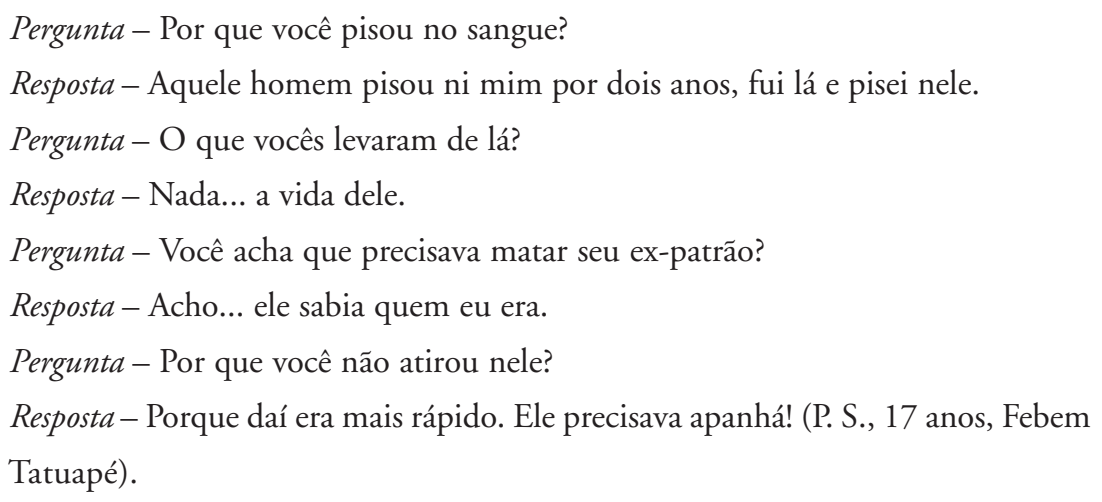

Outro jovem, este de classe média, relatou um caso ocorrido com ele e seu amigo:

Resposta - Tava eu e um amigo meu lá na [avenida] Faria Lima, perto da Dacon. Tava dando uma banda lá e aí a gente pensou em pegar um carro pra gente ir até o Guarujá dar umas volta na praia. Era o quê? Umas dez horas e era sábado ainda. Aí a gente viu um véio num Vectra estacionando numa esquina, assim, perto da avenida. Era um véio que tava manobrando devagarzinho... olhamo e falamo: "Aí, é esse aí?". Amigo meu falou: "Só se for agora!". Eu tava com uma arma, meu amigo tinha um 38. Eu fui na porta do motorista e enquadrei. "Aí, tio, sai! Sai!" O véio falou: "Que sai o quê? Sai você, moleque!". "Porra”, eu falei! Qualé que é desse véio?... "Sai daí, meu!" Meu amigo tentou abrir a outra porta, mas tava travada. Aí, dei um grito "Aí, sai daí véio, se não vou estourar a sua cabeça!" Aí ele parou e ficou olhando pra mim assim... E não saiu... coloquei o cano encostado no vidro e atirei... acho que foi na barriga dele, ele caiu assim pra trás... aí caimo fora...

Pergunta - Na Faria Lima? Ninguém ouviu? 
Resposta - Ah! Quando o homem caiu pra trás saimo correndo... não vi ninguém... Pergunta - O homem morreu?

Resposta - Não sei... acho que não... (P. J., 18 anos, Morumbi, duas passagens pela Febem por roubo. O pai é advogado e possui um carro modelo Vectra, mesmo modelo que ele pretendia levar da vítima).

Esses dois crimes não se enquadram no que poderíamos considerar motivação para o roubo ou mesmo vingança, como no primeiro caso. Apesar de figurar como roubo, eles transcendem as justificativas de aquisição material. Para estudar essas ações devemos levar em consideração a dinâmica emocional que envolve o crime em si e também as próprias definiçôes que o jovem apresenta aos outros, isto é, a auto-imagem que ele elabora. Segundo Katz (1988), devemos prestar atenção nos fatores que relacionam o simbolismo do mal e as emoções de desvio, assim como nas características da prática na cena onde o crime ocorreu.

Os jovens, sobretudo os que habitam a periferia e estão envolvidos em infraçōes graves, passam boa parte do dia sem fazer absolutamente nada. Geralmente, após um assalto, um crime ou outra participação numa ação grave, eles se retiram por um período, ficando fora de combate, "afastados", por algumas semanas, enquanto consomem o fruto do assalto. Os que trabalham com o tráfico estão mais ocupados no final da tarde e à noite, quando todos os gatos são pardos. Normalmente passam o dia vendo televisão, jogando bola nos poucos campos de terra que ainda existem na periferia, dormem, soltam pipa, usam droga e fazem sexo. Nada incomum à vida da maioria dos adolescentes, principalmente se se acrescentasse o item escola a essa lista. Uma vida que, se analisada por quem está fora dela, de certa forma parece até hedonística.

Os jovens que entrevistei, apesar de levarem uma vida em que o crime violento faz parte de seu cotidiano, conseguem combinar outros tipos de ações entre um crime grave e outro. O que é característico é que suas atividades estão entrecortadas pela delinqüência, o que os obriga a levar uma vida difusa, na qual praticamente tudo o que fazem está envolvido por ações ilícitas, desde suas relações mais pessoais, familiares, até o espaço em que transitam. O que os seduz é a própria ação criminosa. Essa talvez seja a grande diferença entre os criminosos jovens e adultos. Os jovens vivem essa qualidade sedutora da ação delinqüente; já os adultos, agem mais racionalmente antes e depois da ação. O jovem busca emoções, enquanto os adultos fazem de sua vida criminosa uma profissão. Um jovem internado na 
Febem Tatuapé relatou o seqüestro relâmpago de uma jovem, próximo ao bairro do Butantã, zona oeste de São Paulo:

\footnotetext{
Resposta - Camarada nosso já tinha dado a fita pra nóis. Eu e outro cara aí esperamo a dona sair, era cedinho, assim sete hora, acho. Mó casão, cara. Ela foi tirando o carro assim de ré, quando saiu na calçada enquadramo, cara. Tirei o trezoitão assim, ô meu! Num tem outra. Ela ficou vermelha, começou a tremer, assim. E eu vai, vai, vai!

Pergunta - O que você sentiu na hora? Lembra?

Resposta - Ô, meu! Senti uma coisa assim, esquisita. O dedo ali, cara, hum, num sei não. O diabo atenta, num atenta? Dá uma vontade de apertá. Mas eu só dei uma assim [um soco] na cabeça dela. Aí a gente foi no carro dela até o banco, mas fui assim, na maió adrenalina, cara! Faltô isso pra apertar o cano! (W. A., 16 anos, Paraisópolis, internado na Febem por esse seqüestro, que acabou na porta do caixa eletrônico, onde foram pegos pela polícia).
}

Esses jovens levam uma vida com uma significação especial e, além de manterem uma estrutura temporal aberta (não há o que fazer com o dia e com a noite a não ser reafirmar a delinqüência), também organizam uma estrutura social que engendra as diferentes linhas de ação. Vivem, assim, constantemente entre dois pólos de instigação social. Por um lado, há a opressão institucional que a todo instante lhes cobra a obediência à ordem e os aconselha a seguir o caminho da "regeneração". Por outro lado, não têm como fugir do mundo da delinqüência. "Devem por essa via atualizar periodicamente seu repertório de práticas deliqüenciais, ampliar seu raio de ação e de contato. Estender seu currículo, se tornar cada vez mais audacioso, enfrentar todos e todas as circunstâncias com que se defrontam em seu caminho tortuoso" (Adorno, 1991, p. 208).

A classificação de desviantes, que os outros elaboram, só vem de encontro às suas expectativas. Há um forte apelo entre esses jovens de se configurarem entre os seus como uma espécie de outsiders. A forma de andar, os gestos com os braços, com as mãos, as gírias utilizadas, não são características apenas do jovem da periferia, mas também estão presentes, pelo menos em parte, entre os adolescentes das classes mais abastadas. Utilizam o corpo como forma de linguagem. Os jovens da classe média "imitam" os jovens da periferia, identificando-se com as roupas, a linguagem, o gestual, o rap que invadiu os condomínios dos bairros nobres da cidade. Ser tachado de marginal pelos outros chega a ser uma conquista. De maneira geral, o pri- 
meiro passo na maioria das carreiras desviantes é a omissão de um ato não conformista. Não é proposital, não há por trás disso uma inconformidade intencional (cf. Becker, 1973).

Em diversos momentos da pesquisa pude constatar que os jovens se sentiam eufóricos em relatar com riqueza de detalhes os assaltos, as mortes, as açôes. Era praticamente impossível anotar tudo o que falavam: as entradas nas casas, as fugas, as mortes das pessoas como se tivessem cometido atos heróicos e a aceitação por parte dos outros, tudo reafirmava esse heroísmo. Apesar de internados na Febem, o relato possuía a mesma emoção. A internação era apenas um detalhe, como se houvesse a necessidade de reafirmar na negação. Há momentos esparsos de resignação, de solidão, mas que são rapidamente suplantados pelas descrições de seus crimes e pela esperança de sair da instituição. São momentos em que esses jovens transcendem um dilema existencial, que é relacional e interno (o que sentem), à identidade exterior (o que pensam deles).

O espaço físico interfere também nessa construção, uma vez que é um espaço de desprazer, principalmente a periferia. É um espaço que sensibiliza negativamente o sujeito, que passa então a lutar contra toda situação desencadeadora de desprazer a fim de conseguir um equilíbrio entre prazer e desprazer (cf. Lorenz, 1988). Um dos resultados dessas ações é que o homem não investe em "empreendimentos que prometem ganho de prazer a longo prazo. $\mathrm{O}$ que resulta uma impaciente demanda de satisfação imediata a cada novo desejo" (Idem, p. 46). Entre um momento desejante e outro, há o vazio que precisa ser preenchido. É a sensação de vazio que assinala o momento em que é preciso preencher os espaços interiores (cf. Sissa, 1999), o que não significa matar, mas também beber, comer, fazer sexo etc. $\mathrm{Ou}$, de outra forma, matar a fome, matar a sede, matar o outro, o que se realiza fora dele. Essa sensação, relacionada com o outro, dependente do outro, está também vinculada ao campo do erótico.

A periferia é muito feia. Os jovens que habitam essas regiōes, em muitos casos, sentem-se envergonhados de mostrar suas residências. A imagem é sempre impregnada de negativismo, desvantagens em relação aos outros bairros e, conseqüentemente, às outras pessoas. Eles demonstram isso num discurso misto de revolta e orgulho: revolta por estarem "abandonados" nessa situação e orgulho pela tentativa de impor-se por esse negativismo.

$\mathrm{O}$ jovem pertencente à classe média tem também esse mesmo posicionamento e os mesmos dilemas. A imagem que prevalece para o senso 
comum é a de que são na verdade um bando de "rebeldes sem causa", mas o sentimento de falta é o mesmo do dos jovens da periferia. Os relatos são os mesmos.

Segundo Bourdieu, pode-se "representar o mundo social em forma de espaço (e várias dimensões) construído na base de princípios de diferenciação, ou de distribuição, constituídos pelo conjunto de propriedades que atuam no universo social considerado, quer dizer, essas propriedades podem conferir, ao detentor delas, força ou poder nesse universo" (2000, pp. 133-134). Cada um dos agentes estaria em posição relativa nesse espaço, cada um numa região determinada dele, e ali os indivíduos estabelecem suas relações. Assim, o espaço pode ser descrito também como "conjunto de relações de forças objetivas impostas a todos os que entram nesse campo e irredutíveis às intenções dos agentes individuais, ou mesmo às interações diretas entre os agentes. $\mathrm{O}$ que existe, portanto, é um espaço de relaçóes o qual é tão real como o espaço geográfico" (Idem, p. 137). É também nesse espaço que os jovens se relacionam e traçam seus objetivos de vida. É aí que falam sobre suas ações e planejam seus "crimes". Esse espaço funciona como estilo de vida e, portanto, não é um espaço qualquer, mas está fortemente marcado e preenchido de signos inclusivos, "que demarcam a presença do controle daquele território pelo grupo ou comunidade [...]. O espaço tende a ser lido assim a partir das categorias absolutas 'nosso' e 'deles', aliás como os demais valores associados a essa dinâmica” (Costa Gomes, 2002, pp. 64-65).

A representação que o jovem tem do mundo social e a construção da visão de mundo oriunda dessa percepção constituem a visão de sua própria posição nesse mundo - é sua identidade social (cf. Bourdieu, 2000). O problema surge quando essa identidade se defronta com a realidade. Isto é, seus anseios e suas vontades são cerceados diante do real, impossibilitando a ele de ser um indivíduo, tomado aqui no sentido dado por Horkheimer de que "não significa simplesmente a existência sensível e espaçotemporal de um membro particular da espécie humana, mas, além disso tudo, a compreensão de sua própria individualidade como um ser humano consciente, inclusive o reconhecimento de sua própria individualidade" (1976, p. 139). Contudo, tanto na periferia como na zona central, a individualidade pressupõe um sacrifício no que diz respeito à realização dos anseios pessoais que ele próprio percebe como difíceis de serem realizados diante da carência a sua volta. E, segundo Horkheimer, o poder social é hoje mais do que nunca mediado pelo poder sobre as coisas. Quanto 
mais "intensa é a preocupação do indivíduo com o poder sobre as coisas, mais as coisas o dominarão, mais lhe faltarão os traços individuais genuínos, e mais sua mente se transformará num autômato da razão formalizada" (Idem, p. 141).

Uma das alternativas é correr riscos, buscar ideais a todo custo. Se ele consegue algo que traga benefício, na esfera legal da jurisdição, sentir-se-á integrado; caso contrário, a resposta à negação será a violência. Os jovens investem nos riscos e ao mesmo tempo, paralelamente, refletem sobre sua existência. Em muitos casos esse investimento é contra outros jovens que possuem uma imagem inversa à deles, ou seja, o que ele busca é o que o outro é, o que o outro tem. Não é raro os jovens da periferia se referirem aos jovens de outras regióes mais abastadas com termos como "riquinho", "boyzinho", "mauricinho", para desmerecê-los, ou então como "cuzão", "bundão", para agredi-los. Ou ainda, numa mistura dos dois: "boyzinhocuzão", "mauricinho-bundão".

Numa ação violenta, como um homicídio, esses jovens buscam a todo custo reverter os signos visíveis de desvantagens no jogo da inserção social (cf. Cassab, 2001) e, sorrindo, negam o sofrimento diante do dano causado. A equação é invertida e a integridade inviolada, pelo menos naquele momento. Na verdade, eles estão vingando os outros fracassos, para obter o respeito que lhes é devido, ou que acreditam que lhes é devido (cf. Katz, 1988).

Para Sennet (1999), o capitalismo provocou um processo de corrosão do caráter, sobretudo naquelas qualidades que ligam os seres humanos uns aos outros e dão a cada um deles um senso de identidade sustentável. As pessoas passaram a agir da maneira como o sistema se impõe, isto é, ele não permite que as pessoas desenvolvam experiências ou construam uma imagem positiva de suas vidas. O caráter, como diz Sennet, concentra-se sobretudo no aspecto a longo prazo de nossa experiência emocional. São traços pessoais que valorizamos em nós mesmos e pelos quais buscamos que os outros nos valorizem, e que dependem de virtudes estáveis como a lealdade, a confiança e a ajuda mútua. Contudo, nota o autor, essas características estão desaparecendo com o capitalismo moderno. As pessoas que não se enquadram nesse novo processo capitalista são jogadas para fora do sistema e, o que parece ser um agravante, sentem-se inferiorizadas e humilhadas diante do fracasso. Estar inserido numa sociedade em que a superabundância é vital e ao mesmo tempo ser excluído dela suscita sentimentos de humilhação e também de ressentimento (cf. Oliveira, 2000) para com o outro. 
Da mesma forma que a sociedade o segrega, o jovem reage atacando-a com o isolamento. A violência é sempre uma resposta a outra violência, é assim que as coisas são percebidas (cf. Dadoun, 1998).

Um jovem que participa do tráfico de drogas no bairro do Capão Redondo explica seus dois trabalhos anteriores ao tráfico da seguinte maneira:

Resposta-Tinha que tá lá sete da manhã. Chegava já tomava dura, tá ligado? Aí, tá atrasado, tá atrasado. Tinha que ficá carregando caixa até as oito, nove, depois ficava empacotando até as cinco. E só dura, só dura. Ia pro almoço, voltava, aí tá atrasado, tá atrasado. Uma vez um saquinho tava furado, caiu a mantega de uma mulher, ele veio me empurrou, sai! Na frente de todo mundo. Que jeito, meu? Até a dona falô: aí, não foi nada. Cê qué o quê?

O outro eu era ajudante de pedrero. Mas ali meu, era que o pesado era comigo, tá ligado? Carrega aquilo, aquele outro. Pega o tijolo, aí faz a massa. E o véio ficava lá, faça isso, faça isso. Tudo eu, tá ligado? Ganhar o quê? Sai! Isso não é vida! E tem também esse negócio de primeiro grau. Tem primeiro grau? Tem segundo grau? Vá se fuder! (P. W., 18 anos, Capão Redondo).

Para ter um tênis de marca que pode proporcionar-lhe satisfação e prestígio diante de seus iguais, um jovem não vê nenhum problema em tirar a vida de outra pessoa, mesmo que seja a de um jovem como ele. Há inúmeros casos na mídia sobre homicídios de jovens que se recusaram a entregar um boné de marca, um tênis da moda ou outro acessório qualquer a um delinqüente.

Ter uma arma também concede poder e prestígio. Atrai a atenção de quem se sente inferiorizado e também de potenciais companheiras, que vêem nisso um sinal de status. Para manter-se nesse meio e satisfazer seu desejo de aquisição, o jovem delinqüente comete outros pequenos crimes que caracterizam o seu cotidiano. Ele leva uma vida especialmente sedutora para quem quer ter algo, e consegue tê-lo grande parte do tempo. Esses pequenos crimes vão desde sair de um bar sem pagar até furtar lojas ou pessoas na rua, e muitas vezes exercem uma atração independentemente do ganho material: furtar um doce na padaria, levar uma peça de roupa qualquer na loja e sair sem pagar, furtar revistas das bancas etc. Não é o valor da mercadoria que justifica o roubo, mas sim o prazer de fazê-lo. O mesmo acontece com o vandalismo e as depredações, ações que não satisfazem o desejo de aquisição, mas o desejo de praticá-las. Praticar o ato é o que importa. Para jovens que picham muros ou monumentos, não é a 
pichação em si que lhes proporciona prazer, mas a proibição do ato. Portanto, quanto mais alto o local, mais difícil o acesso, mais ilícito o ato, maior o prazer. Um doce furtado da padaria é mais gostoso do aquele comprado. Isso transpassa a questão material. O prazer é que os crimes são furtivos e freqüentemente emocionam os praticantes.

A emoção do furto é criada basicamente em três momentos: primeiro, esse tipo de ação gera a experiência de ser seduzido pelo ato ilegal, ilícito, o que torna o sujeito pertencente a um meio, isto é, a algum meio, já que não se sente pertencente a nenhum; segundo, provoca a reconquista das emoções, o que o torna normal; e, por fim, a apreciação do significado reverbera uma emoção de euforia (cf. Katz, 1988). Contudo, esse estilo de vida impõe ao jovem uma constante vigilância que determina seus passos e objetivos de vida, que passa a ser entrecortada pelo inesperado. Ele vive numa espécie de matar ou morrer que toma conta de seu cotidiano.

Esse processo não afeta somente jovens pobres da periferia, mas envolve também jovens de bairros mais abastados da cidade. $\mathrm{Na}$ pesquisa, não encontrei um número elevado de jovens nesses bairros que já tivessem praticado assassinatos. Mas os poucos encontrados demonstram a mesma indiferença para com suas vítimas que os da periferia, com "grande" envolvimento na criminalidade. $\mathrm{O}$ que os iguala é pertencerem à mesma faixa etária e o que os diferencia são as classes sociais distintas. O relato de um jovem de 16 anos, morador do Itaim-Bibi e estudante de um colégio católico do Morumbi, é esclarecedor. Ele nunca foi internado na Febem, mas disse já haver sido preso duas vezes pela Polícia Militar, uma por roubo e outra por agressão. Mas os dois casos, segundo ele, "não deu nada". Tudo foi resolvido com os advogados do pai.

Resposta - A gente tava indo pra [rua] Funchal e entramo numa banca que tem lá perto e ficamo ali olhando. Tinha uma pá de revista legal. Saca aquela do Batman, aquela grandona, nova, do Cavaleiro das Trevas? Então, queria levar aquela. Falei pro cara: Vô levar essa daqui... posso pagar depois? O cara riu e falou: Claro que não! Cê acha que eu vô deixar você levar a revista assim na manha? Nem fudendo! Aquele jeito dele, cara... aquele jeito, meu... nem falei nada... dei um soco na cara dele, meu... ele espatifou no canto da caixa dele. Tava com meu canivete, devia era ter dado uns furo nele. A sorte era que tinha uma pá de gente lá fora. Aí, ele quis levantar, pisei na cara dele! [Rindo] Ah! Seu bosta! Aí, vô levar a revista que eu quiser aqui e cale sua boca, falô? Peguei um livrão que tinha assim na prateleira e taquei nele assim. Ele ficou lá resmungando... 
Pergunta - O que você fez com a revista?

Resposta - A do Batman? Sei lá... acho que nem levei... é não levei nada não...

[rindo] deixei lá, mas foi um barato! (V. R.,16 anos, Itaim-Bibi).

A questão não é somente o roubo, como nesse caso, mas a indiferença descrita, a arrogância e o desprezo para com o outro. É a revelação da carência de referenciais, buscados constantemente, numa espécie de procura insaciável. Esses referenciais não são encontrados claramente demarcados no sistema social. Pelo contrário, o caos em que vivem física e psicologicamente indica que a sociedade não é organizada por apenas uma referência discursiva, mas por diferentes discursos. "Embora seja demandado por ele escolher entre duas formas dominantes do laço social, a reivindicação ou o conformismo, o adolescente identifica um terceiro modo entre exigir e resignar-se. Esta terceira saída é a infração, um misto de subversão do poder do outro e de busca de tutela social" (Oliveira, 2000, p. 106).

Mas voltemos ao prazer de matar.

A emoção em cometer um ato desviante, como, por exemplo, uma simples pichação de muros ou pequenos furtos em lojas ou residências, está presente em jovens tanto de classes mais baixas como nos de abastadas. São as emoções furtivas, como já apontou Katz (1988), que surgem quando uma pessoa tacitamente procura uma experiência na qual ela seja seduzida pelo desejo, pelo ato ilegal, acompanhado de uma sensação de euforia após a realização do ato. Com um pouco de esforço podemos compreender essas pequenas ilegalidades cometidas cotidianamente. Mas como compreender o prazer que alguns adolescentes sentem ao matar? E, mais ainda, com requintes de crueldade. Não é somente matar o outro, mas destruir seu corpo.

Em março de 2000, três adolescentes de 9, 16 e 17 anos mataram com requintes de crueldade outras duas crianças, uma menina de 8 e seu irmão

3. Folha de S.Paulo, "Menino de 9 diz que matou menina de 8", 22/3/2000, pp. 3-1; Revista Época, "Pequenos assassinos", 27/3/2000, p. 47. de $9 \operatorname{anos}^{3}$. O crime ocorreu no município de São Roque, no interior do estado de São Paulo. Os dois irmãos foram convidados a passear pelos três amigos e acabaram entrando num matagal. Ali foram seviciados com paus, pedras e cipós encontrados na mata. Cada um dos adolescentes teria dado também dez pauladas na cabeça dos dois irmãos, além de obrigarem as crianças a comerem fezes. A menina, antes de morrer, teria sido violentada pelos três adolescentes. Para a polícia, o mais velho teria dito: "Nóis três é que matamo. Pegamo um toco e batemo na cabeça deles". Quando questionados, um deles disse: "Quando nóis entrô no mato, nóis entrô com a 
intenção de matá". Não sabiam explicar por que mataram duas crianças amigas deles. $\mathrm{O}$ que impressionou o delegado foi a tranqüilidade dos garotos enquanto estavam sendo interrogados.

Podemos dizer que o mundo moderno, além de isolar o indivíduo e segregá-lo de certos aspectos da convivência social, possibilita uma manipulação do poder em determinados casos. $\mathrm{Na}$ ação estrita do assassinato, podemos perceber certa sensualidade na elaboração do ato. Para Katz (1988), isso só é possível nos indivíduos com um espírito de criminalidade, ou seja, são necessárias uma prática no modo de ação executiva, uma criação simbólica que define a situação e uma fina estética em reconhecer e elaborar uma possibilidade sensual. Intimidar o outro, por exemplo, é uma das formas de criminalidade mais essenciais ao desafio moral de um indivíduo, o ato de impor-se sobre o outro desde a fala até a destruição do corpo do inimigo. Não é somente destruir o outro, mas destruir seu corpo para o social.

A sensualidade mostra-se nessa ação brutal, na forma como se mata, na atitude e no significado de toda a cena onde se desenvolve o acontecimento. Atirar em alguém, esfaquear um corpo, cortar partes dele ${ }^{4}$, esmagar a carne são atos que parecem envolver toda uma sensualidade recheada de significados. Como o jovem que matou seu ex-patrão e antes de sair pisou em seu sangue, numa atitude derradeira de esmagar seu corpo (já sem vida), ou o garoto que assaltou o ônibus e tentou escrever seu nome no rosto do motorista. São tentativas de expurgar algo dentro de si, numa ação envolvida com a sensualidade. Por isso esses jovens provocam o terror. Segundo Elias (1990), o terror está no centro da questão do pudor: o terror de se tornar vulnerável à agressão do outro e, mais especialmente, aos gestos de superioridade de um outro mais forte.

Os garotos aqui citados, assim como a maioria dos outros jovens que concederam entrevistas, relatam suas ações com certo grau de resignação. Não estão revoltados com a nova situação, aceitam o destino como se já estivesse traçado e houvesse sido passado a eles sem questionamentos.

Como o caso de um jovem que, para roubar pouco mais de dezoito reais, matou um senhor com um tiro na cabeça porque ele o "olhou assim" (de cima para baixo) - o olhar de um superior para um inferior, de um melhor para um pior. O desprezo do jovem para com o outro, ao atirar na cabeça de sua vítima, reverteu essa hierarquia. Sentiu-se humilhado apenas com um olhar, mas era um olhar recheado de signos, um olhar que o colocava fora de seu espaço, fora de seu mundo. E se para retornar ao seu universo e restabelecer as relações for necessário o aniquilamento do outro - assim será. Se-
4. "Porque é preciso matá-lo, também, simbolicamente, matá-lo para a sociedade, matar a possibilidade de sua memória como pessoa. Não é apenas retirá-lo como corpo físico, mas também matá-lo para a sociedade" (Martins, 1996, p. 21). 
gundo Eliade, o que caracteriza as sociedades tradicionais é a oposição que elas subentendem entre o território habitado e o espaço desconhecido e indeterminado que o cerca. O primeiro é o mundo, o resto é uma espécie de outro mundo. "Se os deuses tiverem de espancar e de esquartejar um monstro marinho ou um ser para poderem criar o mundo a partir dele - o homem deve imitar essa ação" (Eliade, s/d, p. 64). É dessa maneira que simbolicamente o homem funda o seu próprio mundo.

Não é possível afirmar que a crueldade e o desprezo pela vida de outrem sejam traços característicos do comportamento dos jovens de hoje - autores de infraçóes penais graves -, principalmente pela escassez de estudos históricos e antropológicos que contemplem esse fenômeno. Mas podemos refletir sobre a atualidade dessa forma de comportamento. Quanto à crueldade, enquanto acontecimento, ela talvez traduza um momento de ruptura nas relações.

A emergência da crueldade como expressão recorrente da violência indica que algo se rompeu na sociedade brasileira, uma interrupção de proporçôes consideráveis, uma vez que atravessa os mais distintos campos do discurso, das relações de poder e das possibilidades de conhecimento e de justificativa racional para tais acontecimentos.

A crueldade rompeu com o véu de uma sociedade - a brasileira - cuja identidade esteve até recentemente marcada pela não-violência, pela resolução pacificada dos conflitos e das tensões nas relações sociais, pela preferência pela reforma e pela conciliação. A ruptura discursiva indica que é preciso rever mitos e fabulaçóes; mais do que isso, é preciso incorporar a violência e uma de suas manifestações - a crueldade com que adolescentes e jovens adultos praticam crimes violentos - como traço identitário dessa sociedade. E ela pode indicar também que está ocorrendo uma profunda interrupção nas relações de poder e de dominação tradicionais nessa sociedade. As imagens de passividade e sujeição incontestes dos dominados e das classes populares parecem ter se esfumaçado no ar. As ações dos jovens que cometem infrações podem sugerir expressões radicais de mudanças nas relações hierárquicas e de dominação. Aqueles que tradicionalmente mandavam podem, na atualidade, se converter em vítimas potenciais, ou as vítimas podem estar mesmo entre iguais, entre pessoas que vivem sob as mesmas condiçôes adversas de existência. O desejo de destruir o outro, de impor uma humilhação degradante, indica não apenas a vontade de destruição material do corpo da vítima, mas também de destruição de certa configuração de relações de força sociais cujo campo de gravitação é o corpo 
social. Eliminar o corpo do outro pode significar, entre outras coisas, o desejo de constituição de um novo corpo social, isento dos hábitos tradicionais de mando e obediência. Pode igualmente traduzir disposições sociais, que até há pouco estavam sob a epiderme do corpo social, no sentido de soterrar as formas tradicionais de poder, mando e autoridade, em favor de novas modalidades de sujeição cujos contornos não é possível, no momento, circunscrever.

Esses adolescentes e jovens adultos, autores de crimes graves, podem estar assumindo o papel de porta-vozes dessa nova alteridade em constituição, cujos sinais toscos e grosseiros se espelham na crueldade e na imposição de sofrimento às suas vítimas.

\section{Referências Bibliográficas}

Adorno, Sérgio França. (1991), "A prisão sob a ótica de seus protagonistas, itinerário de uma pesquisa”. Tempo Social, 3: 1-2, São Paulo.

BECKer, Howard. (1973), Outsiders: studies in the sociology of desviance. New York, The Free Press.

Bourdieu, Pierre. (2000), O poder simbólico. Rio de Janeiro, Bertrand Brasil.

CARDIA, Nancy. (1998), "Violência urbana e os jovens". In: São Paulo sem medo, um diagnóstico da violência urbana. Rio de Janeiro, Garamond.

Cassab, Maria Aparecida, (2001), "Jovens pobres e a cidade”. In: Castro, Lucia Rabello (org.), Crianças e jovens na construção da cultura. Rio de Janeiro, Nau/Faperj.

Cohen, Albert K. (1955), Delinquent boys: the culture of the gang. Glencoe, Illinois, The Free Press.

Costa, Márcia Regina da. (1993), Os carecas do subúrbio. São Paulo, Vozes.

Costa Gomes, Paulo César da. (2002), A condição urbana, ensaios de geopolítica da cidade. Rio de Janeiro, Bertrand Brasil.

Dadoun, Roger. (1998), A violência, ensaio acerca do "homo violens". Rio de Janeiro, Difel.

Diógenes, Glória. (1998), Cartografias da cultura e da violência: gangues, galeras e o movimento hip hop. São Paulo, AnnaBlume.

Eliade, Mircea. (s/d), O sagrado e o profano: a essência das religióes. Lisboa, Livros do Brasil.

Elias, Norbert. (1990), O processo civilizador. Rio de Janeiro, Zahar, vol. I e II.

FEBEM - Fundação para o Bem-Estar do Menor. (2000), Relatório Anual, xerox.

FundaçÃo Perseu Abramo. (2001), Resultado de Pesquisa Juventude: cultura e cidadania. Núcleo de Opinião Pública (NOP), São Paulo. 
Glassner, Barry. (1999), The culture of fear. New York, Basic Books.

GUimARĀes, Eloísa. (1998), Escola, galeras e narcotráfico. Rio de Janeiro, UFRJ.

Horkheimer, Max. (1976), Eclipse da razão. Rio de Janeiro, Labor.

IBGE - Instituto Brasileiro de Geografia e Estatística. (2001), "Síntese dos Indicadores

Sociais". São Paulo.

JANKOwsKI, Martin Sanchez. (1991), Islands in the street. California, University of

California Press.

. (1997), "As gangues e a estrutura da sociedade norte-americana". Revista Brasileira de Ciências Sociais, 12 (34), jun.

KATZ, Jack. (1988), Seductions of crime, moral and sensual attractions in doing evil. New York, Basic Books.

KleIN, Malcom W. (1995), The American street gang. Oxford, Oxford University Press.

LoREnZ, Konrad. (1988), Oito pecados mortais do homem civilizado. São Paulo, Brasiliense.

MARTins, José de Souza. (1996), "Linchamento, o lado sombrio da mente conservadora”. Tempo Social, 2, out.

Michaud, Yves. (1998), A violência. São Paulo, Ática.

Oliveira, Roberto Cardoso de. (2000), "Os (des)caminhos da identidade". Revista Brasileira de Ciências Sociais, 42, São Paulo.

SAlem, Helena. (1995), Skins: as tribos do mal. São Paulo, Atual.

SeAde (2000), "Sistema de Estatísticas Vitais para o Município de São Paulo". São Paulo.

Secretaria de Segurança Pública de São Paulo. "Dados do ReS SSP 160/01". São Paulo.

Sennett, Richard. (1999), A corrosão do caráter. Rio de Janeiro, Record.

SISSA, Giulia. (1999), O prazer e o mal. Rio de Janeiro, Civilização Brasileira.

Spagnol, Antonio Sergio. (2003), Garotos perdidos: um estudo sobre os jovens delinqüentes na cidade de São Paulo. Tese de doutorado, São Paulo, Faculdade de Filosofia, Letras e Ciências Humanas da Universidade de São Paulo.

Thompson, Kenneth. (1999), Moral panics. London, Routledge.

Vianna, Hermano. (1988), O mundo funk carioca. Rio de Janeiro, Zahar.

WaiselfisZ, J. J. (coord.). (1998), Juventude, violência e cidadania. Rio de Janeiro, Cortez.

Zaluar, A. (1997), "Gangues, galeras e quadrilhas". In: Vianna, Hermano. Galeras cariocas. Rio de Janeiro, UFRJ. 


\section{Resumo}

Jovens delinqüentes paulistanos

Os jovens que se envolvem em infrações graves na cidade de São Paulo chamam a atenção pela crueldade com que praticam seus atos. São jovens tanto da periferia como de bairros mais abastados. A mídia alardeia esses eventos focando principalmente os jovens da periferia. Fala-se também em gangues na cidade, mas a pesquisa na qual este artigo se baseia não pôde encontrar esse fenômeno. As entrevistas revelam as diferentes formas de atuação desses jovens e a crueldade com que praticam suas ações. Essas ações indicam que as relações baseadas num princípio de reciprocidade estão rompidas, deixando emergir outros laços sociais baseados no fascínio pelo poder e pela destruição do outro. Palavras-chave: Delinqüência juvenil; Homicídios; Gangues; Adolescentes infratores; Jovens delinqüentes; Crueldade.

\section{Abstract}

A Study on delinquent youths in the city of São Paulo

The youths envolved in serious infractions in São Paulo city get the attention for the cruelty with that they practice those actions. They are young, as much of the periphery as of wealthier neighborhoods. The media collaborates boasting those events focusing mainly the youths of the periphery. It is also spoken in gangs in the city, but the research could not find that phenomenon. Through interviews we can notice the different forms of performance of those young ones and the cruelty with that they practice their actions. Those actions indicate that the relationships based on reciprocity are broken letting to emerge other social bows ruled through power attraction and the destruction of the other.

Keywords: Juvenile delinquency; Homicides; Gangs; Adolescents offenders; Delinquents youths; Cruelty.

Texto recebido em $19 /$ $11 / 2004$ e aprovado em $2 / 3 / 2005$

Antonio Sergio Spagnol é doutor em Sociologia pela FFLCH-USP e autor de $O$ desejo marginal (Arte e Ciência, 2001). E-mail: spagnol@usp.br. 